\title{
Reproductive endocrinology and biotechnology applications among buffaloes
}

\author{
ML Madan ${ }^{1}$ and BS Prakash ${ }^{2}$ \\ 'Livestock Production Systems, 842, Sector -6, Urban Estate, Karnal-132001 India; ${ }^{2}$ Division of \\ Dairy Cattle Physiology, National Dairy Research Institute, Karnal - 132001, India
}

\begin{abstract}
Buffalo, as the major livestock species for milk and meat production, contribute significantly to the economy of many countries in south \& south-east Asia, South America, Africa and the Mediterranean. Improved buffalo production could significantly enhance the economy and the living standards of farmers in countries where buffaloes predominate; particularly, in countries with a tropical climate. The major factors limiting the efficient utilization of buffaloes in countries with a tropical climate are: late maturity; poor estrus expressivities, particularly in summer months; long postpartum calving intervals; low reproductive efficiencies and fertility rates which are closely linked with environmental stress; as well as managerial problems. As good reproductive performance is essential for efficient livestock production, the female buffalo calves must grow rapidly to attain sexual maturity, initiate estrous cycles, ovulate and be mated by fertile males or inseminated with quality semen to optimize conception and production. In the last two decades, considerable attention has been focused on understanding some of the causes for the inherent limitations in reproduction among buffaloes by studying their reproductive endocrinology as well as developing biotechniques for augmenting their reproductive efficiency. This review provides an overview of buffalo reproductive endocrinology and also of the research done to date towards the enhancement of buffalo reproductive efficiency through endocrine and embryo biotechniques.
\end{abstract}

\section{Introduction}

There are about 158 million buffaloes in the world and roughly 153 million $(97 \%)$ of these are water buffaloes essentially found in the Asian Region. The overall buffalo numbers are increasing by about $1.3 \%$ annually (FAO 2000). Apart from being the mainstay of the milk production system in many south \& south-east Asian countries, buffalo also contribute to the rural economy in terms of meat production and draught. The riverine buffalo is better adapted than cattle to tropical climates especially with respect to utilization of poor quality roughages and resistance to some of the tropical diseases (Chauhan 1995). This makes buffaloes easy to maintain using the locally available roughage and crop residue. In recent years the buffalo has gained more attention around the world compared to the cow, not just due to its reasonable growth rate on 
roughage feeding, but also due to its high milk yield with high fat percentage, tolerance to hot and humid climates, lean meat and draught ability.

The buffalo, however, is a sluggish breeder and is beset with various constraints which adversely influence its fertility; such as, problems of silent heat coupled with late maturity, poor expression of estrus, irregular estrous cycles, seasonality in breeding, anestrus, low conception rates, long postpartum calving intervals and repeat breeding (Madan 1990). Considerable attention has been focused on the reproductive endocrinology of the buffalo as a means to identify specific problems and devise means to augment reproductive performance. An understanding of hormonal interplay is required for alleviating reproductive problems of an endocrine origin. This knowledge is paramount for biotechnological applications for enhancing the reproductive efficiency in this animal. This review presents a) the state of knowledge on the reproductive endocrinology of the riverine buffalo (Murrah breed) and b) research studies carried out for improving fertility in these species using endocrine biotechniques.

\section{Estrous behaviour}

Reproductive efficiency among large ruminants is greatly dependent upon the detection of estrus. This is even more important with reference to small herds managed under tropical or subtropical environments because high air temperatures shorten the duration of estrus and lower its intensity (Madan \& Johnson 1973; 1975) as demonstrated under controlled environments in cattle. The intensity of estrous behavior in tropical buffaloes has been found to be much less than cows. The usual weak symptoms of estrus in the normal breeding season (September to February) become even weaker during the hot months of summer. Among Murrah buffaloes diurnal patterns of estrous behavior have been observed with $59 \%$ of estruses recorded between 10pm and 6am (Prakash 2002). The maximum occurrences of various heat symptoms were seen in the winter months of November to February while the lowest occurrences were during March to August in a selected group of buffaloes observed throughout the year (Fig. 1) (Prakash 2002). Out of the 8 major symptoms of estrus, 5 symptoms (that is, vulval engorgement, frequent urination, bellowing, bull mounting and restlessness) contributed to 85 percent of the total observations (Fig. 2 and 3). Mucus discharge, licking of the female by the bull and chin resting by the bull were minor symptoms. During the summer months frequent urination was the most prominent heat symptom recorded (Fig. 2).

In another study, the incidence of silent heat occurrences throughout the year was determined in buffaloes by milk progesterone monitoring with the objective of studying the influence of changing environmental temperatures on heat occurrences (Prakash et al. 2005). Out of a total of 292 estruses detected by milk progesterone monitoring 108 estruses $(37 \%)$ went unobserved. The incidence of silent heat was lowest in December (10.5\%) while the peak was seen in April $(70 \%)$. There was a gradual decline in incidence of silent heat occurrence from May onwards (Fig. 4). Due to the high incidence of silent heat, large numbers of buffaloes are left unbred and contribute substantially to a high service period in this animal ( 139 days among 89 buffaloes in this study). Season of calving had a profound influence on the service period. The mean service period of animals calving from December till June was more than 140 days and was significantly higher than mean service period of animals calving in the months of July to November ( $<110$ days). The high service period of buffaloes in the former group of animals was attributed to the high incidence of silent estrus, which the animals would exhibit in the summer months once they commence cycling postpartum (Fig. 5). The effect of different seasons on both the resumption of ovarian activity and embryo survival may be a function of temperature and/or photoperiod: further elucidation by conducting systematic studies uncoupling temperature from photoperiod influences is required. 

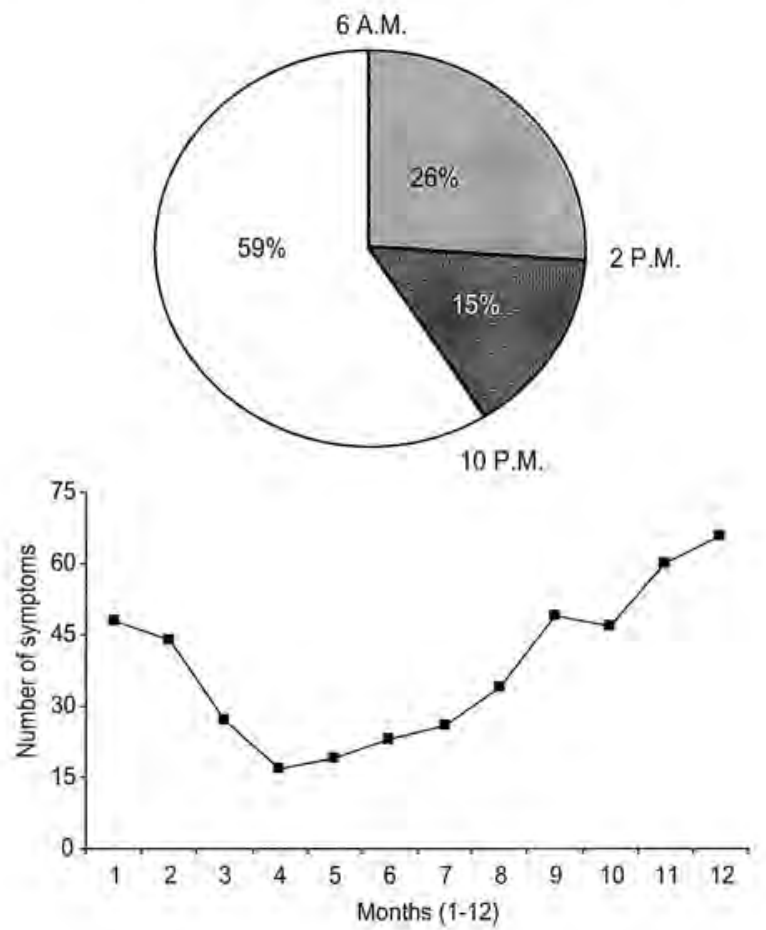

Fig, 1. Variation in number of heat symptoms observed in Murrah buffaloes $(n=13)$ during different months

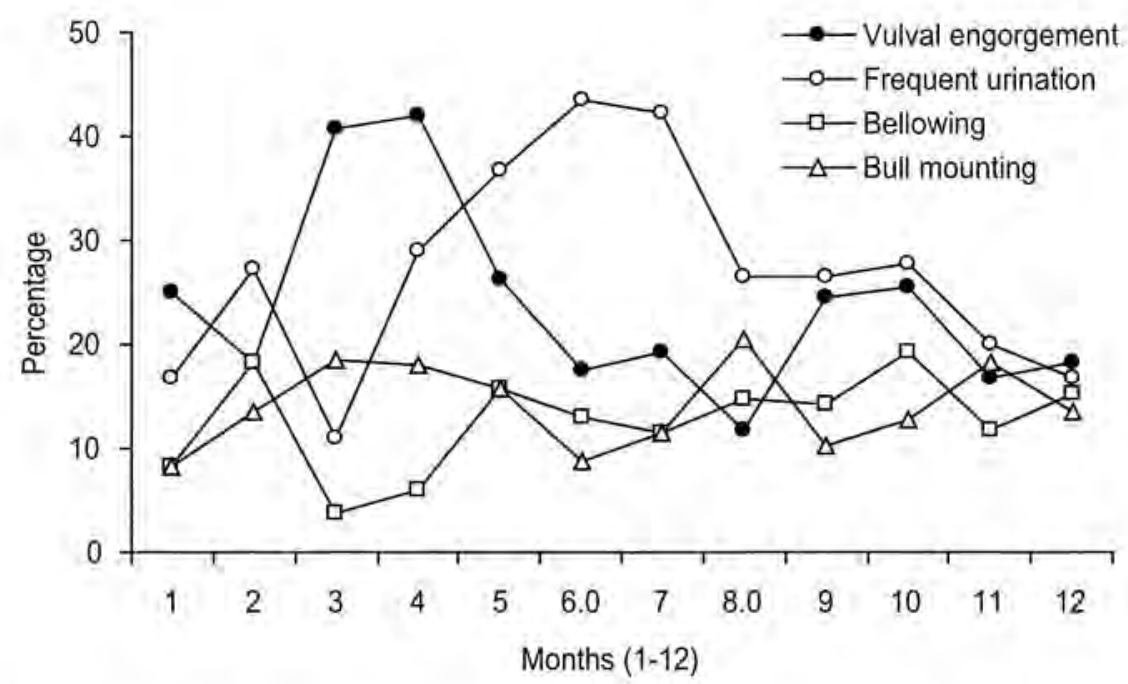

Fig.2. Incidence of various heat symptoms in Murrah buffaloes 


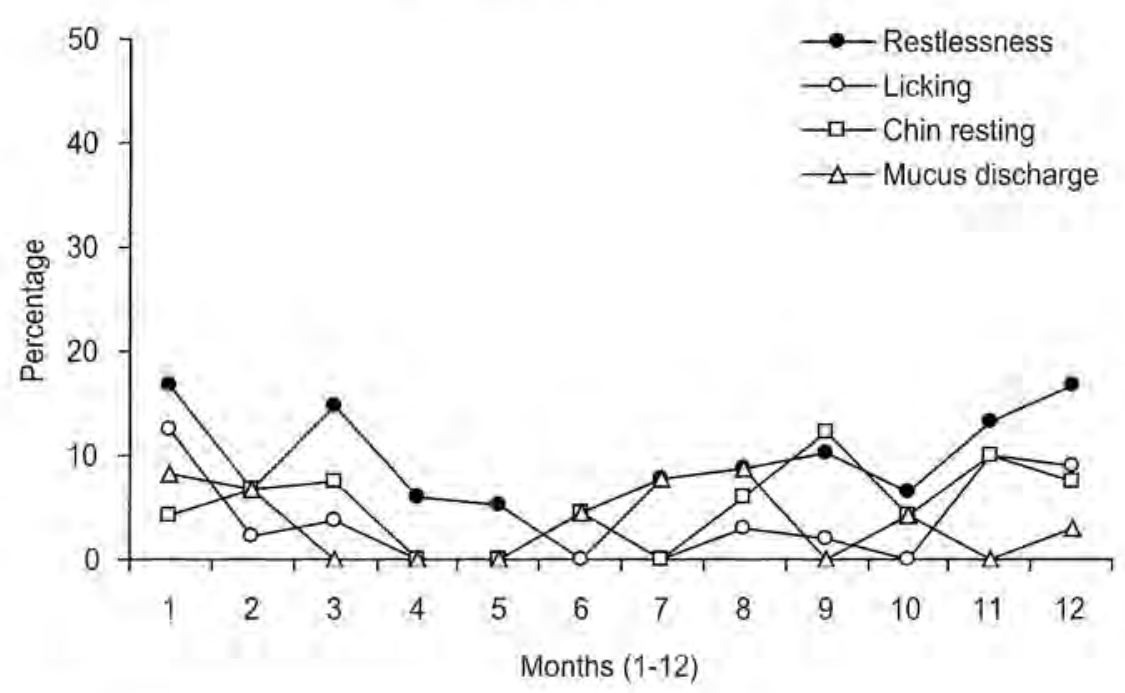

Fig.3. Incidence of various heat symptoms in Murrah buffaloes

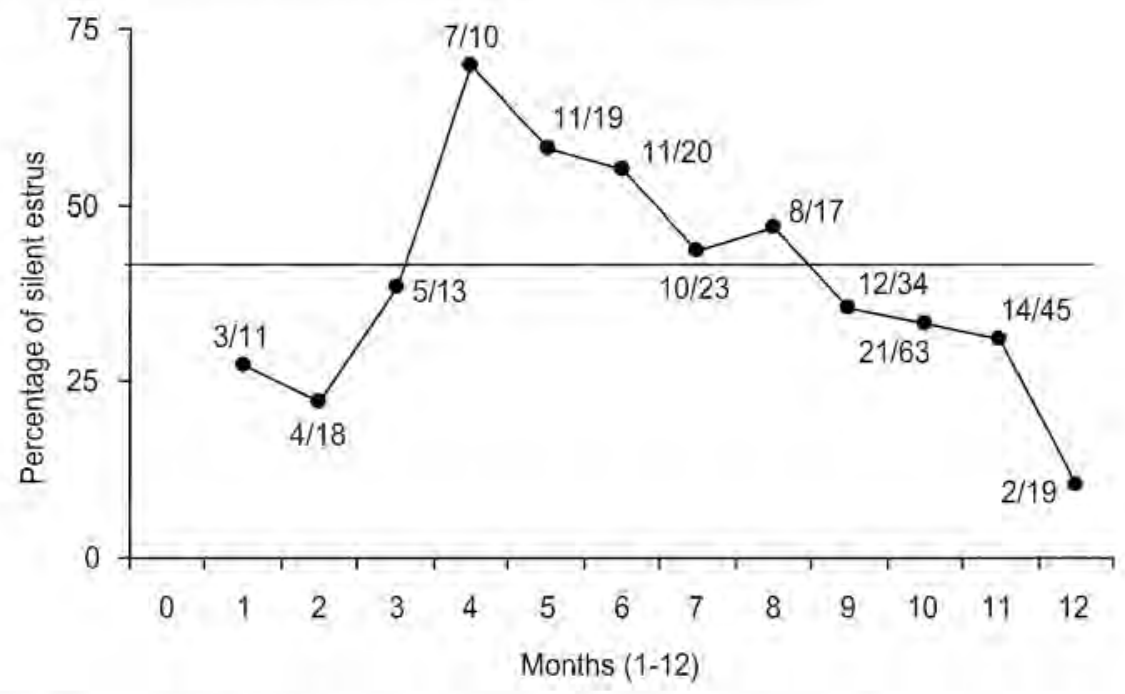

Fig.4. Incidence of silent estrus in buffaloes during different months

\section{The endocrinology of the buffalo estrous cycle}

\section{Progesterone}

Progesterone at appropriate cyclic concentrations is essential for expression of estrus, preparing the uterus for implantation and the maintenance of pregnancy. Essentially, the concentrations of progesterone in peripheral plasma of cycling buffaloes rise and fall in coincidence with the growth and regression of the corpus luteum (CL) (Bachlaus et al. 1979; Kamboj \& Prakash 1993). The reports indicate that concentrations of progesterone in peripheral blood plasma are 


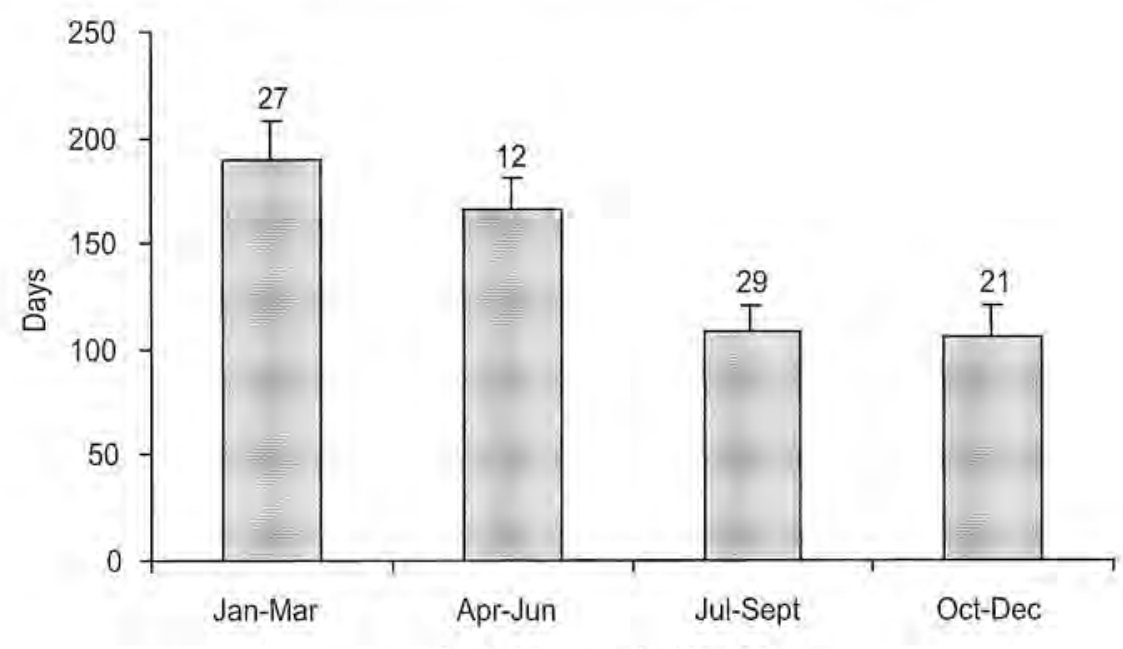

Periods (quarterly intervals)

Fig.5. Influence of month of delivery on service period $(n=89)$

minimal on the day of estrus $(<0.4 \mathrm{ng} / \mathrm{ml})$ and rise to a peak concentrations $(1.0 \mathrm{ng} / \mathrm{ml}$ to $4 \mathrm{ng} /$ $\mathrm{ml}$ ) on days 12-16 of the cycle before declining to a basal level at the onset of next estrus. Circulating progesterone concentrations are lower in hotter months and may therefore be responsible for poor expression of estrus and low conception rates (Rao \& Pandey 1982). Progesterone concentrations have been found to vary with nutritional status in buffaloes. Kaur and Arora (1984) studied circulating progesterone concentrations in a group of buffaloes fed normally ( $7 \mathrm{~kg}$ straw, $2 \mathrm{~kg}$ concentrates and $0.5 \mathrm{~kg}$ dry matter) and in an underfed group ( $65 \%$ less digestible crude protein, $23.8 \%$ less total digestible nutrients than normally fed group). Their results showed that progesterone concentrations were lower in summer than in winter in normally fed buffaloes. The optimum fed buffaloes exhibited weak estruses of short duration during night hours in summer whereas underfed buffaloes did not exhibit any estruses, which lead to persistent infertility. Under-nutrition coupled with high environmental temperature stress was responsible for a long anestrus in buffaloes. The pattern of progesterone in milk is similar to that in plasma but concentrations in milk are higher than those observed in blood plasma due to lipid solubility of steroid (Batra et al. 1979; Kamboj \& Prakash 1993).

\section{Estradiol}

Estrogen induces behavioral symptoms of estrus by its action on the central nervous symptom. Some reports on circulating estradiol concentrations during the estrous cycles of Murrah buffaloes are available (Bachalaus etal. 1979; Kanai \& Shimizu 1984; Avenell et al. 1985). Circulating concentrations of estradiol- $17 ß$ increase following luteolysis and reach a peak value either a day before or on the day of estrus. After attaining the peak concentration, estradiol concentrations in circulation decline to basal levels 2 days following estrus. Minor peaks are detected during the midluteal phase, suggesting the occurrence of additional follicular waves in this species. Buffaloes have been reported to have two or three waves of follicular growth during an estrous cycle with the second wave occurring during days 10-11 of the cycle (Baruselli et al. 1997; Manik et al. 1998). Palta et al. (1996a) reported estradiol-17ß concentrations (ng/ml) of 
$2.40 \pm 0.85,6.27 \pm 2.74$ and $30.29 \pm 11.69$ in small $(3-5 \mathrm{~mm}$ in diameter), medium $(6-9 \mathrm{~mm}$ in diameter) and large (10-12 mm in diameter) buffalo follicles, respectively. The concentrations of estradiol in whole milk are higher and positively correlated with that in plasma during the estrous cycle in buffaloes (Batra et al. 1980). Seasons have been shown to affect estradiol concentrations in blood plasma. Rao and Pandey (1983) reported that whilst estradiol concentrations increase significantly on the day before and on the day of estrus in hot-dry (April to June), hot-humid (July to September), warm (October to December) and cold (lanuary to March) weather, the peak concentrations are lower in summer compared to cooler months. A decrease in the peak concentrations of estradiol around estrus, at the time of decreased progesterone concentrations, may be responsible for the higher incidence of silent estrus during summer (Rao \& Pandey 1982).

\section{Inhibin}

Inhibin, a glycoprotein hormone produced by the granulosa cells of ovarian follicles, suppresses pituitary production and/or secretion of gonadotropins (preferentially FSH) through negative feedback on the pituitary. There are several studies that report the peripheral plasma inhibin concentrations in relation to cyclicity in buffaloes (Palta et al. 1996b; 1997; Mondal et al. 2003a;b). The studies indicated that peripheral inhibin concentrations increase to a maximum concentration 2-4 days preceding estrus and decline subsequently to basal concentrations during the early luteal phase. The significant increase in inhibin concentrations through the late luteal to periestrus phase is suggestive of a vital role of inhibin in folliculogenesis. Inhibin concentrations were significantly higher during the winter season compared to summer (Palta et al. 1997). The lower inhibin concentrations during the summer season could be due to a decline in ovarian activity of buffalo ovaries (Roy et al. 1972). Changing photoperiods do not influence circulating concentrations of either gonadotrophins ( $\mathrm{LH}$ and $\mathrm{FSH}$ ) or gonadal hormones (progesterone and estradiol-17ß) which suggests that environmental stress due to increasing temperature may be influencing follicular turnover and hence inhibin production (Singh 1990). Inhibin concentrations in buffalo follicular fluid are directly correlated with the size of the antral follicle (Palta et al. 1996b;c; 1998). As the population of the follicles of all size categories contributes to the circulating inhibin levels, the pattern of peripheral inhibin concentrations observed in the Singh (1990) study is probably a reflection of the overall follicular population at different stages of estrous cycle.

\section{Follicle Stimulating Hormone}

Gonadotrophin (both LH and FSH) estimations in buffalo plasma have been done using heterologous radioimmunoassays with bovine standards since purified buffalo gonadotrophins are not available. Circulating FSH plays a vital role in the initiation and regulation of the buffalo estrous cycle (Razdan etal. 1982). Several reports are available on peripheral plasma FSH concentrations during the oestrous cycles of buffaloes (Heranjal etal. 1979; Janakiraman et al. 1980; Razdan etal. 1982). Peak concentrations of FSH were detected on the day of estrus in Murrah buffaloes and FSH concentrations declined gradually over the next 3-6 days. Kaker et al. (1980) observed the occurrence of preovulatory surges of $\mathrm{FSH}$. Seasons have been shown to influence peripheral concentrations of FSH. Janakiraman et al. (1980) reported significantly higher FSH concentrations at estrus and during the luteal phase during the peak breeding seasons (November to December; $61.6 \mathrm{ng} /$ $\mathrm{ml}$ ) in comparison to the corresponding times of the cycle during both the medium (July to October; $46.9 \mathrm{ng} / \mathrm{ml}$ ) and low (March to June; $49.1 \mathrm{ng} / \mathrm{ml}$ ) breeding seasons in Surti buffaloes. Lower FSH concentrations during the low breeding seasons were associated with lower follicular activity and the highest incidence of anovulatory cycles. 


\section{Luteinizing Hormone}

During most of the buffalo oestrous cycle the circulating concentrations of $\mathrm{LH}$ are low $(0.72-2.0$ $\mathrm{ng} / \mathrm{ml}$ ) and peak concentrations $(20-40 \mathrm{ng} / \mathrm{ml}$ ) are measured on the day of estrus (Heranjal et al. 1979; Kaker et al. 1980; Arora \& Pandey 1982; Kanai \& Shimizu 1984; Avenell et al. 1985). Higher concentrations of $\mathrm{LH}$ on the day of estrus were observed in cooler months compared to hotter months (Rao \& Pandey 1983). The decrease in peak LH concentrations in hotter months has been attributed, among other causes, to the direct effects of heat stress (Madan \& Johnson 1975). As estrous behavior is controlled by estrogen and progesterone, the decrease in peak concentrations of $\mathrm{LH}$ around estrus would contribute to the higher incidence of silent estrus during the summer.

The accurate detection of preovulatory events facilitates efficient reproductive management in artificial insemination ( $\mathrm{Al}$ ) and embryo transfer programs; for example, knowledge of the timing of ovulation permits the precise timing of Al. In order to assess the exact time of ovulation after onset of estrus, Murrah buffaloes were observed for the onset of estrus by visual observations of the signs of estrus and the females response to a vasectomized bull (teaser) at 0600,1200, 1800 and $2400 \mathrm{~h}$ every day. The time of ovulation was determined by changes in the follicular surface, from turgid at the onset of estrus to flaccid after ovulation, felt by rectal palpation at $2 \mathrm{~h}$ intervals from the onset of estrus till ovulation (Prakash et al. 2005). Blood samples were collected at $2 \mathrm{~h}$ intervals from the onset of estrus till $2 \mathrm{~h}$ after ovulation and the concentration of $\mathrm{LH}$ was assayed in the corresponding plasma samples. Ovulation occurred $42.2 \pm 2.8 \mathrm{~h}$ (range $=28$ to $60 \mathrm{~h}$ ) after the onset of spontaneous estrus and $23.3 \pm 3.5 \mathrm{~h}$ (range $=18$ to $40 \mathrm{~h}$ ) post onset of the peak $\mathrm{LH}$ concentration (Fig. 6). However, initially $\mathrm{LH}$ profile concentrations gradually declined from $2.71 \pm 1.22 \mathrm{ng} / \mathrm{ml}$ at the onset of estrus (0h) to basal levels of $\leq 0.31 \mathrm{ng} / \mathrm{ml} 16 \mathrm{~h}$ later (Prakash et al. 2005).

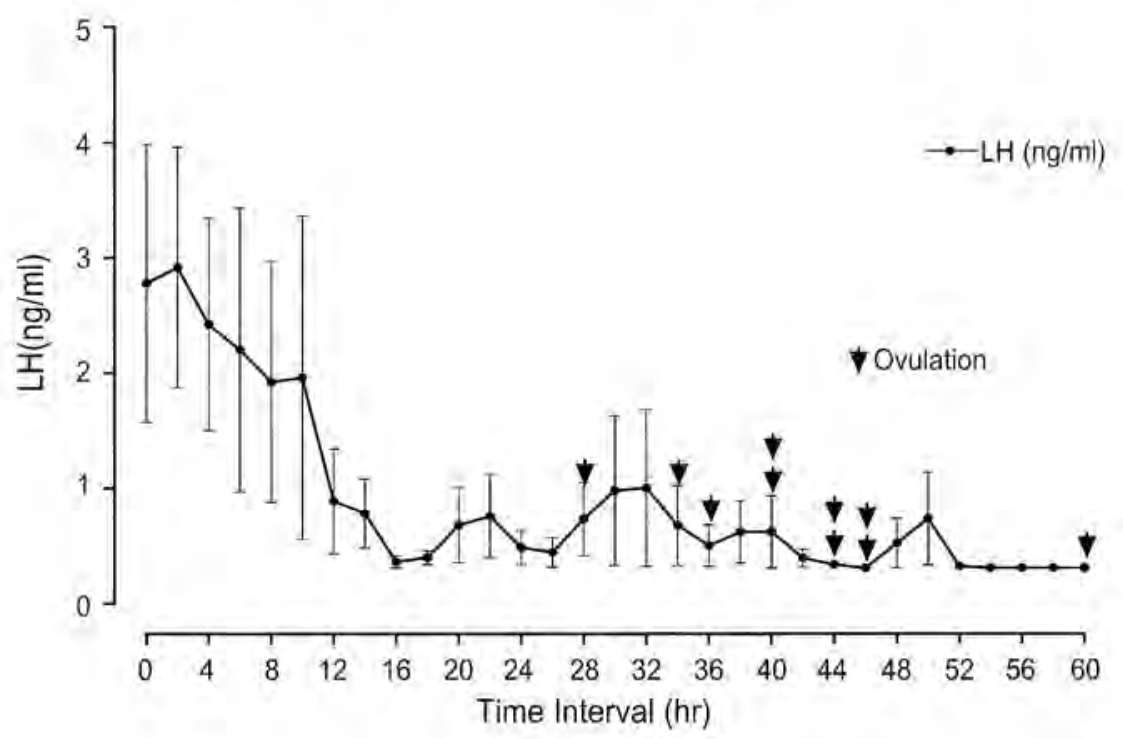

Fig.6. Plasma LH (Mean \pm SEM) profile and timing of ovulation after onset of spontaneous estrus in Murrah buffaloes $(n=10)$

\section{Prolactin}

The concentrations of prolactin in peripheral plasma of buffaloes have been reported by several workers (Heranjal etal. 1979; Razdan \& Kaker 1980; Pahwa \& Pandey 1984; Galhotra etal. 1988; 
Singh \& Madan 1993). Circulating prolactin concentrations are 2-6 fold higher throughout the estrous cycle in the low breeding season (summer) compared to those in either the medium (monsoon) or peak breeding seasons. High concentrations of prolactin during the low breeding season (summer) may be due to an influence of photoperiod on the pineal gland activities of prolactin controlling factors. Plasma prolactin concentrations in cycling buffalo heifers were $248.50 \pm 16.03$ to $369.63 \pm 25.13 \mathrm{ng} / \mathrm{ml}$ in the summer months in comparison to several fold lower concentrations of those observed in the winter months $(3.10 \pm 0.48$ to $9.14 \pm 1.39 \mathrm{ng} / \mathrm{ml})$ without exhibiting a definite trend during cyclicity (Roy \& Prakash 2006). Singh and Madan (1993) reported that prolactin concentrations during summer were higher in non-lactating females than in lactating buffaloes whereas during winter the concentrations were lower in non-lactating females than in lactating buffaloes. The circadian variation in prolactin concentrations was more pronounced in summer than in winter because of greater variation in ambient temperature between morning, noon, evening and night during summer than winter. Very high prolactin concentrations in the summer months were associated with low estrogen concentrations and summer anestrus (Singh \& Madan 1993).

\section{Proslaglandins}

$\mathrm{PGF}_{2 \alpha}$ plays an important role in ovarian function and is involved in both the induction and synchronization of estrus in buffaloes (Bachalaus et al. 1979; Kamonpatana et al. 1976). Mishra et al, (2003) observed a pulsatile pattern of plasma PGFM release prior to estrus when PGFM was determined in blood samples collected at hourly intervals of time. PGFM pulsatility was not observed when a blood sampling frequency of either 4 or 12 hours was used (Batra \& Pandey 1983; Mishra et al. 2003). The increase in PGFM concentrations before estrus coincided with the decline of progesterone concentrations (Batra et al. 1979; Mishra et al. 2003).

\section{Testosterone, cortisol, T3 and T4}

Singh and Madan (1985) reported that mean testosterone concentrations were low from the day of estrus up to day 5 of the cycle with peak concentrations, of approximately $0.10 \mathrm{ng} / \mathrm{ml}$, measured on days 8 and 9 of the cycle. Peripheral plasma cortisol concentrations have been reported to be higher on the day before and day of estrus in Murrah buffalo heifers (Kumar et al. 1991; Madan et al. 1993). During the estrous cycle, mean plasma $T 3$ and $T 4$ concentrations vary between $0.84 \pm 0.16$ $-1.88 \pm 0.10 \mathrm{ng} / \mathrm{ml}$ and $33.28 \pm 5.08-50.76 \pm 8.23 \mathrm{ng} / \mathrm{ml}$, respectively (Khurana \& Madan 1985). On the day of estrus the highest concentrations of $\mathrm{T} 3$ and $\mathrm{T} 4$ are detected: the high concentrations of T3, T4 and cortisol may be due to stress of estrus. Sarvaiya and Pathak (1992) reported that circulating concentrations of T3 and T4 were significantly higher in cycling buffalo heifers compared to anestrus heifers. Higher concentrations of thyroid hormones in cycling animals have also been attributed to the influence of ovarian steroids (D'Angelo \& Fisher 1969) as well as pituitary gonadotrophins (Maqsood 1954).

\section{Endocrine changes in the peripubertal buffalo}

The buffalo suffers from a slow growth rate (Arora 1979) and hence delayed puberty (Pandey 1979): in particular, Indian Murrah, an important dairy breed of buffalo, has been recorded as attaining puberty as late as 33 months of age (National Dairy Research Institute, Karnal, India 1996). Buffaloes have been administered with $\mathrm{GnRH}$ at $12,24,30$ and 36 months to test the 
responsiveness of the hypophysis in terms of both FSH and LH release (Singh \& Madan 1998a; b; 2000a). The mean basal circulating concentrations of plasma FSH among the heifers of 12 months of age were lower than at 24 and 30 months. Whereas the basal concentrations of plasma $\mathrm{LH}$ among the heifers at 12 months were higher than plasma $\mathrm{LH}$ concentrations measured among buffaloes of 24 and 30 months of age. Peri-pubertal animals displayed a steady increase in basal $\mathrm{LH}$ production and a decline in $\mathrm{LH}$ peak concentrations with advancing age indicating that the process of sexual maturation of buffaloes was associated with an increase in basal circulating $\mathrm{LH}$. Though the gonadotrophin release pattern after administration of $\mathrm{GnRH}$ (single injection) was nearly similar in these animals, animals of different age groups and reproductive cycle status differed in terms of magnitude of release of gonadotrophin and time taken to reach the peak response post GnRH injection (Singh \& Madan 1998a;b; 2000b; 2002a).

Buffalo heifers at 36 months of age have lower circulating concentrations of both estrogen and progesterone than heifers of 24 and 30 months of age. These results are suggestive of the possible lack of intrinsic hypothalmo-hypophyseal-gonadal interplay as seen among the adults. Administration of a non-hypophyseal gonadotrophin (pregnant mare's serum gonadotrophin: PMSG) to animals of 36 months of age resulted in a gradual increase in estrogen concentrations associated with follicular development (Singh \& Madan 1999a;b) and phasic production of progesterone. In terms of follicular and ovulatory responses to exogenous PMSG adminstration, heifers of 12 months responded better with an increased number of follicles ovulating $(7.1 \pm 0.7)$ than the heifers of 24 months $(5.3 \pm 1.0)$ and 36 months $(4.0 \pm 1.0)$ of age (Singh \& Madan 1999a;b). A GnRH injection at PMSG-induced estrus in prepubertal buffaloes caused synchronized ovulations of large sized follicles and reduced the intervals from onset of estrus to ovulation and also between the first and last ovulation. The plasma prolactin concentrations at 12 months of age were significantly higher than at 24,30 and 36 months and administration of GnRH did not affect prolactin release (Singh \& Madan 2000c; 2002b).

In buffalo heifers the beginning of ovarian activity depends on live weight; in fact, it has been determined that buffaloes have normal estrous cycles when they attain two thirds of their adult body weight (Esposito et al. 1992). Nutrition therefore plays an important role in the timing of the beginning of reproductive activity. In the Mediterranean buffalo (Esposito et al. 1992) there is a delay in the onset of puberty when in the months preceding puberty the diet has insufficient energy. In a study that evaluated the effect of long term and short term nutritional management on conception patterns at first mating in Mediterranean buffalo heifers, it was found that long term nutritional management had a major influence on the age and live weight at first conception (Campanile et al. 2001). Heifers that were kept on a constant and relatively high plane of nutrition conceived at a younger age (540 days of age) compared with heifers that were fed on a low plane of nutrition ( 840 days of age). Similar results have also been observed by Barkawi et al. (1989) and Barnabe et al. (1997) in like studies.

The interplay of endocrine mechanisms leading to the transition from sexual quiescence to sexual function and the interaction with growth rate, live weight, metabolic changes and age in buffaloes were investigated (Haldar \& Prakash 2005). A group of Murrah buffalo heifers (21.92 \pm 1.09 months of age, $269.67 \pm 7.97 \mathrm{~kg}$ body weight) were assigned to a diet to provide weight gain of $0.4 \mathrm{~kg} /$ day. Heifers attained puberty at an average age of $31.53 \pm 0.88$ months with $380.67 \pm 6.42 \mathrm{~kg}$ body weight. Circulating progesterone concentrations were very low $(0.20-0.30 \mathrm{ng} / \mathrm{ml})$ during the pre-pubertal period. Plasma $\mathrm{LH}$ and $\mathrm{GH}$ concentrations increased $(\mathrm{P}<0.05)$ over the months preceding puberty and were highest during the month before puberty: plasma GH and $\mathrm{LH}$ concentrations were positively correlated prior to $(\mathrm{r}=+0.59 ; \mathrm{P}<0.05)$ as well as after puberty $(\mathrm{r}=+0.42 ; \mathrm{P}<0.05)$. There was a positive correlation between plasma $\mathrm{LH}$ concentrations and body weight during the pre-pubertal period $(r=+0.61 ; \mathrm{P}<0.05)$ and thereafter a negative correlation during the post-pubertal period $(r=-0.64 ; \mathrm{P}<0.05)$. Plasma 
GH concentrations and body weight were positively correlated both before puberty $(r=+0.92$ : $\mathrm{P}<0.01)$ and after puberty $(\mathrm{r}=+0.32 ; \mathrm{P}<0.05)$. These results suggest that both $\mathrm{GH}$ and $\mathrm{LH}$ are equally important and vital cues in inducing the onset of ovarian function in buffalo heifers.

\section{Endocrinology of gestation and parturition in buffaloes}

Palta and Madan (1996) measured a significant reduction in plasma FSH concentrations in Murrah buffaloes from days 60 to 240 of gestation. However, they did not observe any significant changes in the basal plasma LH concentrations in the same period. During the last stages of pregnancy, $\mathrm{LH}$ concentrations fluctuated narrowly between 0.4 and $0.9 \mathrm{ng} / \mathrm{ml}$ in riverine buffaloes (Galhotra et al. 1981; Barkawi et al. 1986). Kamonpatana (1984) also reported low circulating concentrations of LH in Swamp buffaloes during the 10 days before and after parturition.

In peripartum Murrah buffaloes mean plasma estradiol-17ß concentrations increased gradually from 30 days preterm to 5 days preterm followed by a steep increase to peak concentrations on 1 day prepartum (Prakash \& Madan 1984a; 1986). The mean plasma progesterone concentrations declined gradually from $1.82 \mathrm{ng} / \mathrm{ml} 30$ days preterm to $1.21 \mathrm{pg} / \mathrm{ml} 2$ days prepartum, then fell sharply to low levels at calving (Prakash \& Madan 1985a; 1986). Mean PGF concentrations remained low $(<0.75 \mathrm{ng} / \mathrm{ml})$ up to day 2 prepartum, increasing substantially to $1.86 \mathrm{ng} / \mathrm{ml}$ on day 1 prepartum, followed by a steep rise to a peak value of $4.16 \mathrm{ng} / \mathrm{ml}$ at partum (Prakash \& Madan 1985a). The mean plasma cortisol concentrations remained more or less constant during the pre-and postpartum periods rising sharply to a peak at calving (Prakash \& Madan 1984b; 1986). The pattern of change in the concentrations of the hormones was essentially similar to those recorded in peripartum cows (Thorburn et al. 1977).

\section{Endocrine Changes in the buffalo postpartum}

Postpartum anestrus remains a major reproductive limitation in buffalo. The calving to calving interval in $48-66 \%$ of buffalo is $>14$ months as a result of the environment and unpredictable management (Perera 1999). Buffaloes are susceptible to many stressors that seriously affect reproductive efficiency; especially, day length, high temperatures and nutritional deficiencies. Suckling is encouraged in buffalo to enhance calf survival rate and facilitate milk let down but unfortunately this practice also attenuates the neuroendocrine signals required for resumption of ovarian activity. Studies have been attempted for reducing post-partum anestrus in buffaloes but protocols still require refinement (Tiwari \& Pathak 1995).

\section{Progesterone}

Routine determinations of milk progesterone concentrations indicated that the interval from calving to first postpartum commencement of cyclicity is highly variable with a mean of around 68 days in Murrah buffaloes (Prakash et al. 2005). This also contributes to the large service period in this animal. Postpartum anestrus has also been classified in terms of a) non detection of animals in estrus due to poor estrus expressivity and behavioral estrus signs or b) as "true anestrus" when the ovaries are non-cyclic with no follicular development or CL formation (Madan et al. 1984). Such animals do not respond to luteolytic compounds for estrus induction. However, animals showing phasic cycles with progesterone undulations in diestrous phase, respond to such compounds. 


\section{FSH and LH}

During the postpartum period baseline plasma FSH concentrations were significantly higher $(P<0.01)$ on day 20 , compared to the concentrations obtained on day 2 , but did not differ significantly from the concentrations obtained on day 35 postpartum (Palta \& Madan 1996). However when milked buffaloes were compared with suckled buffaloes there were no significant differences in plasma FSH concentrations between days 3 and 90 postpartum or between milked and suckled buffaloes (Arya \& Madan 2001a). In two separate studies, no significant changes in basal plasma LH concentrations were detected between days 3 to 90 postpartum or the first 4 months postpartum during which period the buffaloes did not exhibit any estrus (Arya \& Madan 2001a; Galhotra et al. 1981), There were also no significant changes in plasma LH concentrations between milked and suckled Murrah anestrous buffaloes (Arya \& Madan 2001a). However, in another study there was a progressive increase in basal plasma LH concentrations from days 2 to 35 postpartum (Palta \& Madan 1995). The responsiveness of the pituitary gland to $\mathrm{GnRH}$ administration in terms of $\mathrm{LH}$ and FSH release was drastically increased $(\mathrm{P}<0.01)$ between days 2 and 20 postpartum, although the responsiveness to $\mathrm{GnRH}$ administration during advancing gestation in buffaloes showed a declining trend in gonadotrophin release (Palta \& Madan 1996). In conclusion, there appears to be insufficient gonadotrophic support for follicular growth and development during the early postpartum period.

\section{Prolactin and $\mathrm{CH}$}

Prolactin is absolutely crucial for galactopoesis and whilst the suckling stimulus is of a certain quality, and that quality is thought to be read by the hypothalamus by the pattern and concentration of prolactin release, the hypothalamic-pituitary-ovarian axis is suppressed although it is not clear by what mechanism(s). Growth hormone is a known anabolic hormone and has been seen to play a role in enhancing growth and early commencement of puberty in buffaloes (Mondal \& Prakash 2003; 2004; Haldar \& Prakash 2006). Hence the principle hormones, which could be playing a major role in determining the length of postpartum period for cyclicity commencement, are prolactin and $\mathrm{GH}$. While no significant correlation was found between $\mathrm{GH}$ concentrations and days to commencement of cyclicity, the correlation of plasma prolactin concentrations with commencement of cyclicity was highly significant $(r=0.90, P<0.01$ : Prakash et al. 2005): the high plasma prolactin concentrations are probably associated with low release of gonadotrophins and hence the inhibitory effect on cyclicity as has been recorded in cattle in earlier investigations.

\section{Estrogens}

After parturition the plasma estradiol-17ß concentrations decline steeply during the first $24-72 \mathrm{~h}$ (Arora \& Pandey 1982; Pahwa \& Pandey 1983; Prakash \& Madan 1984a). Circulating estradiol-17ß concentrations were basal between days 2 and 7 after calving (Prakash \& Madan 1986; Arya \& Madan 2001b) and continued to stay low until 45 days postpartum (Madan et al. 1984). These observations are also indicative of delayed follicular development postpartum in this species.

\section{Reproductive Technologies for augmenting buffalo reproduction}

Over the years, arrays of options have been studied for the reproductive management of buffaloes. Such management systems are now being fine-tuned with the aim of increasing pregnancy rates and thereby increasing the overall reproductive efficiency among buffaloes. Endocrine techniques, like estrus detection, estrus synchronization, pregnancy diagnosis, induction of parturition, corpus 
luteum control et cetera, have been found useful for augmenting fertility. Second generation strategies aimed at maximizing genetic improvement are also being introduced; for example, assessment of spermatozoa quality through fertilization capacity, sexing spermatozoa, synchronization and fixed time insemination, superovulation (SO), embryo transfer (ET) and in vitro embryo production (IVEP). Reproductive technologies are also credited with controlling the incidence of reproductive diseases when the procedures and protocols are accurately followed.

\section{Augmentation of growth for early puberty in buffaloes}

Growth hormone $(\mathrm{GH})$ has been long recognized as a potent regulator of an animal's growth however repeated direct administration of exogenous $\mathrm{GH}$ for increasing growth has met with limited success due to negative feed back mechanism mediated by IGF-I (Berelowitz et al. 1981). As a better alternative, growth hormone releasing factor (GRF), also called Somatoliberin, which controls the expression of $\mathrm{GH}$ in more physiological context, has been reported as a better potential growth promoter in cattle (Lapierre et al. 1992; Moseley et al. 1987; Sejrsen et al. 1996). In recent studies the effectiveness of repeated exogenous GRF administrations was proved with respect to a sustained release of $\mathrm{GH}$ along with the growth promotion in growing buffalo calves during a long course of treatment and led to the hypothesis that repeated GRF administration had the potential for inducing early onset of puberty in buffalo species (Mondal \& Prakash 2005). Subsequently, the successful application of GRF administration for advancing puberty in buffaloes has been demonstrated (Haldar \& Prakash 2006).

\section{Augmentation of fertility through progesterone monitoring}

Monitoring changing concentrations of progesterone in blood plasma or milk provides an objective evaluation of ovarian activity. Concentration changes in samples collected twice weekly provide a very convenient indicator of buffalo luteal activity (Gupta \& Prakash 1990; Kaul et al. 1993). The sequential monitoring of progesterone can be used to detect ovulation, estimate the proportion of cycling females in a group, determine whether inseminations have been correctly performed and diagnose and treat reproductive disorders (Kamboj \& Prakash 1993; Kaul etal. 1993; Kaul \& Prakash 1994a). Another important use of progesterone determination in blood plasma or milk is in terms of early (around days 22-24 post insemination in buffaloes) pregnancy and non-pregnancy diagnosis for which the test is about 75\% and 100\% accurate, respectively (Gupta \& Prakash 1990; Kaul \& Prakash 1994b).

The tremendous utility of progesterone assays has evolved considerable interest in simplifying the assaying procedure. A simple radioimmunoassay (RIA) method for progesterone estimation, which is completed in a few hours, has been developed and requires no prior extraction of the samples as was previously required (Prakash \& Madan 1986; Kamboj \& Prakash 1993; Gupta \& Prakash 1993). This new assay has been further refined by the use of a highly sensitive and specific antiserum (Prakash \& Madan 2001). Quantitative enzyme-immunoassays (EIA) for estimating the hormone in blood plasma and milk of buffaloes have also been developed (Prakash et al. 1990; 1992a). The ElA technique is advantageous in situations where facilities do not exist for radioisotope handling.

Pregnancy confirmation through estrone sulphate determination

Estrone sulphate has been found to be quantitatively one of the major estrogens in the blood 
plasma and milk of pregnant and lactating cows and buffaloes. During the first half of pregnancy its concentrations increase gradually so that after 100 days of pregnancy it is present in all milk samples taken from pregnant cows and buffaloes, whereas it is low or undetectable in non-pregnant animals (Hung \& Prakash 1990; Prakash \& Madan 1993). Measurement of estrone sulphate in milk on a routine basis could serve as a viable test for pregnancy confirmation and hence also the detection of the presence of mummified fetuses (Prakash \& Madan 1994).

\section{Estrus synchronization}

Various methods to induce the regression of the $\mathrm{CL}$ and the induction of estrus in buffaloes have been developed but are beset with their own advantages and disadvantages. The effectiveness of all these protocols is dependent upon the precision of estrus detection and knowing the time of ovulation after synchronization (Singh et al. 2000). Several methods of estrus synchronization using progestogens, $\mathrm{PGF}_{2 \alpha}$ and the combination of both are available (Macmillan \& Burke 1996). The use of two $\mathrm{PGF}_{z \alpha}$ injections at an interval of 11 to 14 days is the most popular technique for estrus synchronization in buffaloes. However, the behavioural signs of estrus expressed after a synchronized estrus are much weaker than those expressed after a spontaneous estrus making estrus detection more difficult. A new estrus synchronization protocol in cattle, called Ovsynch, has been developed: it makes use of a combination of GnRH-PGF $_{2 \alpha}-\mathrm{GnRH}_{\text {injections (Pursley et }}$ al. 1995). The efficacy of using this estrus synchronization protocol in Murrah buffaloes in tropical conditions has been examined (Paul \& Prakash 2005). The conception rates obtained after fixed time Al using the Ovsynch protocol were similar to those obtained from buffaloes inseminated at observed heat. The authors have also compared their results using the Ovsynch protocol with the two injections of $\mathrm{PGF}_{2 \alpha}$ protocol for synchronization (V Paul \& BS Prakash, unpublished data: Tables 1 and 2).

Table 1. Conception rates of buffaloes inseminated after spontaneous estrus and induced estrus using Iwo different protocols for the synchronization of estrus (V Paul \& BS Prakash, unpublished data)

\begin{tabular}{|c|c|c|c|}
\hline \multirow[t]{2}{*}{ Treatment } & \multicolumn{2}{|c|}{ Number of buffaloes } & \multirow[t]{2}{*}{ Conception rate $(\%)$} \\
\hline & Inseminated & Pregnant & \\
\hline \multicolumn{4}{|l|}{ Spontaneous estrus } \\
\hline (Control group) & 75 & 23 & 30.7 \\
\hline \multicolumn{4}{|l|}{ Ovsynch } \\
\hline (GnRH-PGF $\left.{ }_{z x}-G n R H\right)$ & 15 & 5 & 33,3 \\
\hline Two injections of PGF $2 x$ & 15 & 4 & 26.7 \\
\hline
\end{tabular}

Table 2. Analysis of efficacy of estrus synchronization and timed artificial insemination (V Paul \& BS Prakash, unpublished data)

\begin{tabular}{lccccc}
\hline Treatment & $\begin{array}{c}\text { Number of } \\
\text { estrusesobserved }\end{array}$ & $\begin{array}{c}\text { Number of estruses } \\
\text { unobserved }\end{array}$ & $\begin{array}{c}\text { Total number } \\
\text { of estruses }\end{array}$ & $\begin{array}{c}\text { Number of } \\
\text { animals conceived }\end{array}$ & $\begin{array}{c}\% \\
\text { Conception }\end{array}$ \\
\hline Control & 75 & $25^{*}$ & 100 & 15 & 23.0 \\
Ovsynch & 15 & -15 & 5 & 33.3 \\
Two injections of PGF & 15 & & 4 & 26.7 \\
\hline
\end{tabular}

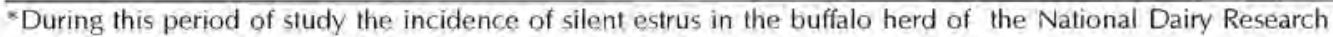
Institufe (NDRI) was reported to be $25 \%$ (Prakash 2002)

*- Timed artificial insemination was performed $24 \mathrm{~h}$ after the second GnRH treatment for Ovsynch group; and

72 and $96 \mathrm{~h}$ after second $\mathrm{PGF}_{2 \alpha}$ injection for the two injections of $\mathrm{PGF}_{2 \alpha}$ group.
} 
Prolactin inhibition in repeat breeding buffalo heifers in the summer

A study was undertaken to investigate the efficacy of the Ovsynch protocol for estrus synchronization with or without anti-prolactin (Norprolac) administration in repeat breeding Murrah buffalo heifers following timed artificial insemination during the summer season (KS Roy \& BS Prakash, unpublished data). A dose of $10 \mathrm{mg}$ Norprolac administered intramuscularly resulted in prolactin suppression. Plasma progesterone profiles indicated that a high percentage (36 to $45 \%$ ) of repeat breeding buffalo heifers became acyclic during the peak summer months. The Ovsynch protocol without prolactin inhibition was beneficial in terms of reducing the incidence of anestrus from $45 \%$ before treatment to only $18 \%$ after treatment. Norprolac induced prolactin suppression improved the efficiency of the Ovsynch treatment as there was no incidence of acyclicity post-treatment compared to $36 \%$ acyclicity before treatment. The Ovsynch protocol plus Norprolac treatment induced more estrus symptoms per animal than the Ovsynch protocol alone (3.7 vs. 2.5).

\section{Parturition induction}

Synthetic glucocorticoid, namely dexamethasone, has been successfully used to induce parturition in buffaloes (Prakash \& Madan 1985b). Inducing parturition in buffaloes is useful in clinical cases of uterine prolapse, which is often seen in this species, and other cases of maternal ill health (such as, limb fractures, pericarditis, reticulitis, hydroamnios and hydroallantois) as well as a potential management tool for synchronizing parturition. It can also be useful in terminating prolonged gestations. Parturition induction in buffaloes may however result in placental retention (Prakash \& Madan 1986).

\section{Recombinant cytokines and their potential application in the maintenance of pregnancy}

In a recent study, recombinant interferon alpha administration on days 14 to 16 of the buffalo estrous cycle not only prolonged the length of the estrous cycle but also significantly reduced the oxytocin-stimulated increase in plasma PGFM concentrations normally detected on day 17 of the cycle (DP Mishra \& BS Prakash, unpublished data). These results suggested that interferon alpha may indeed be a signal for the maternal recognition of pregnancy in buffaloes as has already been demonstrated in cattle by earlier workers. The authors went on to demonstrate an improvement in fertility (60\% conception rates) in buffaloes treated with recombinant interferon $(16 \mathrm{mg} /$ day on days 14 to 16 : the dose was divided between morning and evening adminstrations) post $\mathrm{Al}$ (the normal conception rate in the herd around the same time was $35 \%)$.

\section{Assessment of semen quality and artificial insemination}

The most important and early technology that has helped in the improvement of buffalo reproductive efficiency has been the processing and evaluation of semen for national Al programs. Unfortunately the desired impact in animal improvement schemes has remained wanting because both the fertility and conception rates in field programs are very low. Most of the semen banks use only spermatozoa motility as a criterion for semen evaluation despite considerable advances in semen evaluation processes. There is also considerable information available regarding the processing, storage and thawing of buffalo semen (Sansone et al. 2000) however the processing and handling procedures of many semen processing laboratories and banks leave 
much to be desired. The ultimate fertility/conception rate results obtained in $\mathrm{Al}$ programs often suffer from this acute inadequacy.

\section{Embryo transfer}

Multiple ovulation and embryo transfer (MOET) is one of the major reproductive technologies that facilitates the genetic improvement of the bovine. Unfortunately, high variability in the ovarian follicular response to gonadotrophin stimulation continues to be the major problem in commercial MOET programs. MOET, that takes Al one-step further, both in terms of genetic gains possible and the level of technical capacity and organization required, is one of the basic technologies required for the application of more advanced reproductive biotechnologies; such as, cloning and the generation of transgenics.

The response to superovulation treatments in zebu cattle and buffaloes is considerably inconsistent compared to results obtained in Bos taurus (Barros \& Nogueira 2001). However, it is important to note that the average number of transferable embryos produced by zebu donors has improved in the last 10-15 years: ranging from 2.4 to 5.8 embryos per flush in the late 1980 s to 5.6 to 9.9 transferable embryos in 2000 (Barros \& Nogueira 2001). The application of ET technology in buffalo has had limited success (Singla et al. 1996; Misra et al. 1999). The low embryo production is thought to be due to several reasons: the inherently low reproductive efficiency of buffalo (Singh et al. 2000); their poor superovulatory response (Madan et al. 1996); and a very low primordial follicle population combined with a higher incidence of atresia (Manik et al. 2002). Poor superovulatory responses in buffaloes were also due to the failure to respond optimally to the Lutalyse treatment used for estrus induction (Prakash et al. $1992 a ; b)$. It has also been hypothesized that ova trapping by the fimbriae of the fallopian tubes may not be as efficient in this species, especially following superovulation. Over the years numerous trials in buffalo using various types of hormonal treatments for induction of superovulation have resulted in highly variable responses with a mean recovery of around 2 transferable embryos per flush (Madan et al. 1996). However, in subsequent studies Misra et al. (1999) found better superovulatory responses using Folltropin with a viable embryo recovery of 2.8 . Following the transfer of embryos to recipients, the conception rates are very low (16\%: Singla et al. 1996). Since the introduction of embryo transfer technology in buffaloes in India, more than 186 calves have been produced (Misra et al. 2005).

\section{In vitro production of embryos}

Since the birth of the first buffalo calf from an IVF oocyte (Madan et al. 1991), there have been a number of publications on in vitro embryo production systems describing the effects of different protocols and medium conditions on buffalo oocyte and embryo development. Two extensive reviews have been published recently (Gasparrini 2002; Nandi et al. 2002). However, practical use of IVF is limited due to the high production costs and lower overall efficiency under field conditions. The high rates of oocyte maturation (70 to $90 \%$ ), fertilization (60 to $70 \%$ ) and cleavage ( 40 to $50 \%$ ) in contrast to the moderate to low rates of blastocyst formation (15 to $30 \%$ ) and calf production $(10.5 \%$ ) have been reviewed (Nandi et al. 2002). Viable buffalo blastocysts can be produced from abattoir ovaries (Madan et al. 1994a; b) but the rate of transferable embryos remains low (15 to 39\%: Chauhan et al. 1997; 1998; 1999; Nandi et al. 1998; 2002). In vitro produced embryos have been successfully used for producing pregnancies and live calves in buffalo (Madan et al. 1994b; Chauhan et al. 1997) but the success rates in terms of yield of transferable embryos and number of calves born has been low. 
Ovum pickup (OPU) and in vitro embryo production (IVEP) has been successfully applied to buffaloes even though the efficiency is low in terms of the number of punctured follicles (Galli et al. 2001; Manik et al. 2002). The use of OPU and IVEP may represent a valid approach to speed up genetic improvement by decreasing the generation interval. Repeated OPU techniques yield a large number of meiotically competent oocytes from individual donors, which can then be used for IVEP programs. It has been demonstrated that OPU is competitive with superovulation because it can yield more transferable embryos per donor on a monthly basis (2.0 vs. 0.6: Gasparrini 2002). It has been estimated that a selection scheme based on OPU and IVEP if applied in a closed nucleus of farms will decrease the generation interval from 6.28 to 3.25 yrs compared when progeny testing is used. In fact, the use of OPU combined with IVEP, allows the selection of young bulls on the basis of half and full sibling's milk production rather than their daughters.

The application of nuclear transfer procedures (Singla et al. 1997) also holds the potential for producing large numbers of identical offspring (cloning): a technology which can be used for the multiplication of genotypes of superior economic value. The technology of embryo sexing and the production of buffalo calves of pre-determined sex has also been achieved (Appa Rao et al. 1993).

On account of the low milk production and considerable variability in the genetic potential of buffaloes, the technique of embryo transfer has been exploited for practical application by utilizing the female population as surrogate mothers for the production of high yielding calves. Embryo cryopreservation and the easy transport of cryopreserved embryos have already proved useful under field conditions to obtain large numbers of progeny from young high yielding donors. This procedure has greater relevance in buffaloes, since high potential progeny tested bulls are not available in large numbers as they are in cattle. The technique of in vitro fertilization also holds great promise in harvesting the ova from high producing buffaloes which are transported to metropolitan cities to supply milk and then subsequently lost as they are slaughtered after lactation. Realizing the full potential of the practical application of these technologies, particularly the techniques of nuclear transfer and embryo sexing, will be difficult because of the high costs involved.

\section{Conclusions}

This review provides a comprehensive account of the information available on buffalo endocrinology during different physiological states associated with reproduction, along with the endocrine techniques and potential technologies for augmentation of reproduction. An important research objective is to produce recombinant buffalo gonadotrophins: these may improve the consistency of the responses to superovulatory treatment, an extremely important requirement for the greater success and practical application of embryo transfer in this species. Research efforts also need to be intensified in understanding the mechanism(s) that regulate the expression of estrus in buffaloes; including further investigations into the molecular endocrinology of the ovarian follicle, follicular recruitment, atresia and follicular dominance. Understanding all these aspects are essential for unraveling the causes for silent heat in this species. Understanding the causes of early embryonic mortality, particularly the specific genes involved at the level of the ovum/embryo-uterine interaction, are potentially critical approaches for fertility augmentation. The positive correlation obtained between plasma prolactin concentrations and the delay in the postpartum commencement of cyclicity in buffalo needs further investigation. The control of prolactin secretion could hold the key for reducing the postpartum interval to first estrus in the species. Although, a number of biotechniques have been developed for the 
improvement in reproductive efficiency of the buffalo, these have to be adopted at the field level in a big way if they are to make an impact towards increasing milk production from this species.

\section{References}

Appa Rao KBC, Pawshe CH \& Totey SM 1993 Sex determination of in vitro developed buffalo (Bubalus bubalis) embryos by DNA amplification. Molecular Reproduction and Development 36 291-296.

Arora SP 1979 Management and feeding of calves from birth for early maturity. In Proceedings of FAO / SIDA / Govt. of India Symposium on Buffalo Reproduction and Artificial Insemination, pp 319-326, Dec 4-15, National Dairy Research Institute, Karnal, India.

Arora RC \& Pandey RS 1982 Plasma concentrations of progesterone, oestradiol-17b and luteinizing hormone in relation to repeat breeding in buffalo (Bubalus bubalis). Animal Production 34 139-144.

Arya JS \& Madan ML 2001a Postpartum gonadotrophins in suckled and weaned buffaloes. Indian Veterinary lournal 78 406-409.

Arya IS \& Madan ML 2001b Postpartum reproductive cyclicity based on ovarian steroids in suckled and weaned buffaloes. Buffalo lournal 17 361-369.

Avenell JA, Saepudin Y \& Fletcher IC 1985 Concentrations of $\mathrm{LH}$ and progesterone in the peripheral plasma of Swamp buffalo cow (Bubalus bubalis) around the time of estrus. Journal of Reproduction and Fertility 74 419-424.

Bachalaus NK, Arora RC, Prasad A \& Pandey RS 1979 Plasma levels of gonadal hormones in cycling buffalo heifers. Indian fournal of Experimental Biology 17 823-825.

Barkawi AH, Shafie MM \& Abul-Ela MB 1986 Prepartum hormonal profile in Egyptian buffaloes. Buffalo Journal 2 117-124.

Barkawi AH, Mokhless EM \& Bedeir LH 1989 Environmental factors affecting age al puberty in Egyptian buffaloes. Bulfalo lournal 5 71-78.

Barnabe RC, Barnabe VH, Guido MC, Baruselli PS \& Zogno MA 1997 Onset of ovarian activity in Murrah buffalo heifers. In Proceedings of $V$ World Buffalo Congress, pp 702-705, Oct 13-16.

Barros CM \& Nogueira MF 2001 Embryo iransfer in Bos indicus caltle. Theriogenology 56 1483-1496.

Baruselli PS, Mucciolo RG, Vistin JA, Viana WG, Arruda RP, Maduriera EH, Oliveira CA \& MoleroFilho JR 1997 Ovarian follicular dynamics during the oestrous cycle in buffalo (Bubalus bubalis). Theriogenology 47 1531-1547.

Batra SK \& Pandey RS 1983 Relative concentrations of 13, 14 dihydro-15 keto-prostaglandin F2a in blood and milk of buffaloes during oestrous cycle and early pregnancy. Journal of Reproduction and Fertility 67 191-195.

Batra SK, Arora RC, Bachalaus NK \& Pandey RS 1979
Blood and milk progesterone in pregnant and nonpregnant buffalo. Journal of Dairy Science 621390 1393.

Batra SK, Arora RC, Bachalaus NK, Pahwa GS \& Pandey RS 1980 Quantitative relationships between oestradiol-17b in the milk and blood of lactating buffaloes. Journal of Endocrinology 84 205-209.

Berelowitz M, Szabo M, Frohman LA, Firestone 5 \& Hintz RL 1981 Somatomedin-C mediates growth hormone negative feedback by effects on both the hypolhalamus and the pituitary. Science 2121279 . 1281.

Campanile G, Di Palo R, Gasparrini B, D'Occhio MJ \& Zicarelli L 2001 Effects of early management system and subsequent diet on growth and conception in maiden buffalo heifers. Livestock Production $5 \mathrm{ci-}$ ence 71 183-191.

Chauhan TR 1995 Buffalo Nutrition in India: a review. Buffalo Journal 2 131-148.

Chauhan MS, Katiyar PK, Singla SK, Manik RS \& Madan ML 1997 Production of buffalo calves through in-vilro fertilization. Indian Journal of Animal $5 \mathrm{ci}$ ence 67 306-308.

Chauhan MS, Singla SK, Palta P, Manik RS \& Madan ML 1998 In vitro maturation and fertilizalion, and subsequent developmenl of buffalo (Bubalus bubalis) embryos: effects of oocyte quality and type of serum. Reproduction, Fertility and Development 10 173-177.

Chauhan MS, Singla SK, Palta P, Manik RS \& Madan ML 1999 Effect of epidermal growth factor on the cumulus expansion, meiotic maturation and development of buffalo oocytes in vitro. Veterinary Record 144 266-267.

D'Angelo SA \& Fisher IS 1969 Influence of oestrogen on the pituitary-thyroid system of the female rat. Mechanism of Lactation. Endocrinology $\mathbf{8 4} 117-122$.

Esposito L, Di Palo R, Campanile G, Boni R \& Montemurro N 1992 Onset of ovarian aclivity in Italian buffalo heifers. In Prospect of Buffalo Production in the Mediterranean and Middle East, pp374377, 9-12 $\mathrm{Nov}_{r}$ Cairo, Egypt.

FAO 2000 Food and Agriculture Organisation of United Nations. Livestock Production Statistics, Rome, Italy

Galhotra MM, Kaker ML \& Razdan MN 1981 Serum LH levels during pre- and post-puberty, pregnancy and lactation in Murrah buffaloes. Theriogenology 16 477-481.

Galhotra MM, Kaker ML, Lohan IS, Singal SP \& Razdan MN 1988 Thyroid and prolactin status in relation to production in lactating Murrah. In Proceedings of $2^{\text {nd }}$ World Buffalo Congress, Vol I, 32-34, 
New Delhi, India.

Galli C, Crotti G, Notari C, Turini P, Duchi R \& Lazarri G 2001 Embryo production by ovum pick up from live donors. Theriogenology 55 1341-1357.

Gasparrini B 2002 In vitro embryo production in buffalo species: state of art. Theriogenology 57237 256.

Gupta M \& Prakash BS 1990 Milk progesterone determination in buffaloes post-insemination. British Veterinary Journal 146 563-570.

Gupta M \& Prakash BS 1993 Development of direct rapid radioimmuno-assays for progesterone in milk and fat-free milk of buffaloes. Indian loumal of Animal science 63 1206-1211.

Haldar A \& Prakash BS 2005 Peripheral patterns of growth hormone, luteinizing hormone and progesterone before, at and after puberty in buffalo heifer. Endocrine Research 31 295-306.

Haldar A \& Prakash BS 2006 Growth hormone releasing factor (GRF) induced growth hormone advances puberty in female buffaloes. Animal Reproduction Science 92 254-267.

Heranjal DD, Sheth AR, Desai R \& Rao SS 1979 Serum gonadotropins and prolactin levels during oestrous cycle in Murrah buffaloes. Indian journal of Dairy Science 32 247-249.

Hung NN \& Prakash BS 1990 Changes in estrone and estrone sulphate concentrations in blood plasma of Karan Swiss cows and Murrah buffaloes throughout gestation. British Veterinary Journal 146 449-456.

Janakiraman K, Desai MC, Amin DR, Sheth AR, Moodbidr SB \& Wadadekar KB 1980 Serum gonadotropin levels in buffaloes in relation to phases of oestrous cycle and breeding periods. Indian Journal Animal Science 50 601-606.

Kaker ML, Razdan MN \& Galhotra MM 1980 Serum LH concentrations in cyclic buffalo (Bubalus bubalis). Journal of Reproduction and Fertility $60419-424$.

Kamboj M \& Prakash BS 1993 Relationship of progesterone in plasma and whole milk of buffaloes during cyclicity and early pregnancy. Tropical Animal Health and Production 25 185-192.

Kamonpatana M, Luvira Y, Bodipaksha P \& Kunawongkrit A 1976 Serum progesterone, 17-hydroxy progesterone and $17 \mathrm{~b}$-oestradiol during oestrous cycle in Swamp buffalo in Thailand. In Nuclear Techniques in Animal Production and Health, pp. 569-578, International Atomic Energy Agency, Vienna, Austria.

Kamonpatana M 1984 Application of hormone assay and endocrine pattern in buffalo. In Proceedings of the $10^{\text {th }}$ International Congress on Animal Reproduction and Artificial Insemination, Vol IV, pp. 1-9, Urbana, Illinois, USA.

Kanai Y \& Shimizu H 1984 Plasma concentrations of $\mathrm{LH}$, progesterone and oestradiol during oestrous cycle in Swamp buffaloes (Bubalus bubalis). loumal of Reproduction and Fertility 70 507-510.

Kaul V \& Prakash BS 1994a Application of milk progesterone estimation for determining the incidence of false oestrus detection and ovulation failures in zebu and crossbred cattle and Murrah buffaloes, Indian Journal of Animal Science 64 1054-1057.

Kaul V \& Prakash BS 1994b Accuracy of pregnancy/ non-pregnancy diagnosis in zebu and crossbred catle and Murrah buffaloes by milk progesterone determination post insemination. Tropical Animal Health and Production 26 187-192.

Kaul V, Rao SVN \& Prakash BS 1993 Reproductive status monitoring by milk progesterone determination in rural anestrus and repeat breeding bovines. Indian Journal of Animal Science 63 1132-1135.

Kaur H \& Arora SP 1984 Annual pattern of plasma progesterone in normal cycling buffaloes (Bubalus bubalis) fed two different levels of nutrition. Animal Reproduction Science 7 323-332,

Khurana ML \& Madan ML 1985 Thyroidal hormone during oestrous cycle in cattle and buffaloes. Indian Journal of Dairy Science 38 119-123.

Kumar R, Jindal R \& Rattan PJS 1991 Plasma hormonal profiles during oestrous cycle of Murrah buffalo heifers, Indian Journal of Animal Science 61 382-385.

Lapierre H, Tyrrell HF, Reynolds CK, Elsasser TH, Gaudreau P \& Brazeau P 1992 Effects of growth hormone-releasing factor and feed intake on energy metabolism in growing beef steers: whole body energy and nitrogen metabolism. lournal Animal Science 70(3) 764-772.

Macmillan KL \& Burke CR 1996 Effect of oestrous cycle control on reproductive efficiency. Animal Reproduction Science 42 307-320.

Madan ML 1990 Factors limiting superovulation responses in embryo transfer programs among buffaloes. Theriogenology 33280.

Madan ML \& Johnson HD 1973 Environmental heal effects upon bovine LH. Journal of Dairy Science 56 1420-25.

Madan ML \& Johnson HD 1975 Heat stress effects upon bovine reproductive cycle. In Selected Topics in Environmental Biology, p 207. Eds B Bhatia, G Chinna \& Baldev Singh. New Delhi, India: Interprint publications.

Madan ML, Singh Mahendra, Prakash BS, Naqvi SMK \& Roy AK 1984 Poslpartum endocrinology of buffalo. In Proceedings of the 10th International Congress on Animal Reproduction and Artificial Insemination, Vol. III, pp 402-404, Urbana, Illinois, USA.

Madan ML, Singla SK, Jailkhani S \& Ambrose D 1991 In-vitro fertilization and birth of first ever IVF buffalo calf. In Proceedings of the Third World Buffalo Congress, Vol 2, pp. 11-17. Varna, Bulgaria.

Madan ML, Prakash BS, Jailkhani S, Singla SK, Palta P \& Manik RS 1993 Buffalo endocrinology with special reference to embryo transfer. Technical report publication No.265, p 32, National Dairy Research Institute, Karnal, India.

Madan ML, Chauhan MS, Singla SK \& Manik RS 1994a Pregnancies established from water buffalo (Bubalus bubalis) blastocysts derived from in vitro fertilized oocytes and co-cultured with and oviductal cells. Theriogenology 42 591-600.

Madan ML, Chauhan MS, Singla SK \& Manik RS 1994b 
In vitro production and transfer of embryos in buffaloes. Theriogenology 41 139-143.

Madan ML, Das SK \& Palta P 1996 Application of reproductive technology to buffaloes. Animal Reproduction Science 42 299-306.

Manik RS, Singla SK, Palta P \& Madan MI 1998 Real time ultrasound evaluation of change in follicular populations during oestrus cycle in Buffalo. Indian Journal of Animal Science 68 1157-1159.

Manik RS, Palta P, Singla SK, Sharma V \& Madan ML 2002 Folliculogenesis in buffalo (Bubalus bubalis): A review. Reproduction and Fertility Development $14315-325$.

Maqsood M 1954 Role of thyroid hormone in reproduclion. Indian Veterinary Journal 31 23-30.

Mishra DP, Meyer HHD \& Prakash BS 2003 Validation of a sensitive enzyme immunoassay for 13, 14 dihydro-15-keto-PGF2a in buffalo plasma and its application for reproductive health status monitoring. Animal Reproduction. Science78 33-46.

Misra AK, Muthu Rao M, Kasiraj R, Ranga Reddy NS \& Pant HC 1999 Factors affecting pregnancy rate following non-surgical embryo transfer in buffalo (Bubalus bubalis) - a retrospective study. Theriogenology 52 701-707.

Misra AK, Pragsad S \& Taneja VK 2005 Embryo transfer technology (ETT) in cattle and buffalo in India: A review. Indian Journal of Animal Science 75842 857.

Mondal M \& Prakash BS 2003 Changes in plasma GH, $\mathrm{LH}$ and progesterone and blood melabolites following long term exogenous somatoliberin administration in growing buffaloes (Bubalus bubalis). Journal of Animal and Veterinary Advances 2(4) 259-270.

Mondal M \& Prakash BS 2004 Effects of long-term growth hormone-releasing factor (GRF) administration on pattern of $\mathrm{GH}$ and $\mathrm{LH}$ secretion in growing female buffaloes (Bubalus bubalis). Reproduction $12745-55$.

Mondal M \& Prakash BS 2005 Effects of long-term growth hormone-releasing factor treatment on growth, feed conversion efficiency and dry matter intake in growing female buffaloes (Bubalus bubalis). lournal of Animal Pliysiology and Animal Nutrition 89 260-267.

Mondal S, Prakash BS \& Palta P 2003a Relationship between peripheral plasma inhibin and progesterone concentrations in Sahiwal cattle (Bos indicus) and Murrah buffaloes (Bubalus bubalis). Asian-Australian Journal of Animal Science 16 (1) 6-10.

Mondal S, Prakash BS \& Palta P 2003 b Peripheral plasma inhibin concentrations in relation to expression of oestrus in Murrah buffaloes (Bubalus bubalis). Indian Journal of Animal Science 73(4) 405-407.

Moseley WM, Huisman I \& Van Weerden EJ 1987 Serum growth hormone and nitrogen metabolism responses in young bull calves infused with growth hormone-releasing factor for 20 days. Domestic Animal Endocrinology 451.

Nandi S, Chauhan MS \& Palta P 1998 Influence of cumulus cells and sperm concentration on cleavage rale and subsequent embryonic development of buffalo (Bubalus bubalis) oocyles matured and fertilized in vilro. Theriogenology 50 1251-1262.

Nandi S, Raghu HM, Ravindranatha BM \& Chauhan MS 2002 Production of buffalo (Bubalus bubalis) embryos in vitro: premises and promises. Reproduction in Domestic Animals 37 65-74.

Pahwa GS \& Pandey RS 1983 Gonadal steroid hormone concentrations in blood plasma and milk of primiparous and multiparous pregnant and non pregnant buffaloes. Theriogenology 19 491-505.

Pahwa GS \& Pandey RS 1984 Prolactin in blood plasma and milk of buffalo during oestrous cycle and early pregnancy. Journal of Dairy Science 67 2001-2005.

Palta P \& Madan ML 1995 Alterations in hypophyseal responsiveness to synthetic $\mathrm{GnRH}$ at different postpartum intervals in Murrah buffaloes (Bubalus bubalis). Theriogenology 44 403-411.

Palta P \& Madan ML 1996 Effect of gestation on GnRH induced $\mathrm{LH}$ and $\mathrm{FSH}$ release of buffalo (Bubalus Bubalis). Theriogenology $46993-998$.

Palta P, Jailkhani S, Prakash BS, Manik RS \& Madan ML 1996a Development of direct radioimmunoassay for oestradiol-17b delermination in follicular fluid from individual buffalo ovarian follicles. Indian journal of Animal Science 66 126-130.

Palta P, Prakash BS \& Madan ML 19966 Peripheral inhibin levels during oestrous cycle in Murrah buffalo (Bubalus Bubalis). Theriogenology 45 655-664.

Palta P, Prakash BS, Manik RS \& Madan ML $1996 \mathrm{C}$ Inhibin in individual buffalo ovarian follicles in relation to size. Indian Journal of Experimental Biology $34606-608$.

Palta P, Mondal S, Prakash BS \& Madan ML 1997 Peripheral plasma inhibin levels in relation to climatic variation and stage of oestrous cycle in buffalo (Bubalus bubalis). Theriogenology 47 989-995.

Palta P, Bansal N, Prakash BS, Manik RS \& Madan ML 1998 Follicular fluid inhibin in relation to follicular diameter and oestradiol-17b, progesterone and lestosterone concentrations in individual buffalo ovarian follicles. Indian Journal of Experimental Biology 36 768-774.

Pandey RS 1979 Hormonal status of female and induced breeding in Murrah buffaloes. In Proceedings of FAO / SIDA / Govt. of India Symposium on Buffalo Reproduction and Artificial Insemination, pp 185-197, Dec 4-15, National Dairy Research Instilute, Karnal, India.

Paul V \& Prakash BS 2005 Efficacy of the Ovsynch protocol for synchronization of ovulation and fixedtime artificial insemination in Murrah buffaloes (Bubalus bubalis). Theriogenology 64 1049-1060.

Perera BMAO 1999 Reproduction in water buffalo: comparative aspects and implications for management. Journal of Reproduction and Fertility 45157 168.

Prakash BS 2002 Influence of environment on animal reproduction. In National Workshop on Animal Climate Interaction, pp 33-47, held at Izatnagar, India.

Prakash BS \& Madan ML 1984a Radioimmunoassay of 
cortisol in peripheral blood plasma of buffaloes periparlum. Theriogenology 22 241-245

Prakash BS \& Madan ML 1984b Radioimmunoassay of estradiol $17 B$ in buffaloes peripartum. Indian journal of Experimental Biology 22 104-105.

Prakash BS \& Madan ML 1985a Periparturient plasma progesterone and prostaglandin F (PGF) levels in buffaloes (Bubalus bubalis). Indian Joumal of Animal Science 55 642-646.

Prakash BS \& Madan ML 1985b Induction of parturition in water buffaloes (Bubalus bubalis). Theriogenology 23 325-331.

Prakash BS \& Madan ML 1986 Peripheral plasma oestradiol-17B, progesterone and cortisol in buffaloes induced to calve with dexamethasone and vetoestrol. Animal Reproduction Science 11 111-122.

Prakash BS \& Madan ML 1993 Influence of gestation on oestrone sulphate concentration in milk of zebu and crossbred cows and Murrah buffaloes. Tropical Animal Health and Production 25 94-100.

Prakash BS \& Madan ML 1994 Oestrone sulphate determination in milk for detection of foetal death in bovines. Indian lournal of Animal Science 64 56-58.

Prakash BS \& Madan ML 2001 Production and characterization of a sensitive antiserum against progesterone. Indian lournal of Animal Science 71 251-253.

Prakash BS, Madan ML, Jailkhani S \& Singla SK 1990 Development of a simple direct, microtiterplate Enzymeimmunoassay (EIA) for progesterone determination in whole milk of buffaloes. British Veterinary lournal 146 571-576.

Prakash BS, Singla SK, Ambrose JD, Jailkhani S \& Madan ML 1992a Determination of milk progesterone profiles by a sensitive, direct, enzymeimmunoassay in superovulated buffaloes. Theriogenology 37 897-905.

Prakash BS, Jailkhani S, Singla SK \& Madan ML 1992b Application of a sensitive, heterologous enzyme-immunoassay for progesterone determination in unextracted buffalo plasma samples collecled in an embryo transfer experiment. Animal Reproduction Science 27 67-74.

Prakash BS, Sarkar M, Paul Vijay, Mishra DP, Mishra A \& Meyer HHD 2005 Postpartum endocrinology and prospects for fertility improvement in the lactating riverine buffalo (Bubalus bubalis) and yak (Poephagus graunnies L.) Livestock Production Science 98 13-23.

Pursley JR, Mee MO \& Wiltbank MC 1995 Synchronization of ovulation in dairy cows using PGF2a and GnRH. Theriogenology 44 915-923.

Rao LV \& Pandey RS 1982 Seasonal changes in the plasma progesterone concentration in buffalo cow (Bubalus bubalis). Journal of Reproduction and Fertility 66 57-61.

Rao LV \& Pandey RS 1983 Seasonal variations in oestradiol-17b and luteinizing hormone in the blood of buffalo cows (Bubalus bubalis). Journal of Endocrinology $98251-255$.
Razdan MN \& Kakar ML 1980 Summer sterility and endocrine profiles of buifaloes. Indian Dairyman 32 459-464.

Razdan MN, Kaker ML \& Galhotra MM 1982 Serum FSH levels during oestrus and a 4-week period following mating in Murrah buffaloes (Bubalus bubalis). Theriogenology 17 175-181.

Roy KS \& Prakash BS 2006 Development and validation of a simple, sensitive enzymeimmunoassay (EIA) for quantification of prolactin in buffalo plasma. Theriogenology 67 572-579.

Roy DT, Bhattacharya AR \& Luktuke SN 1972 Estrus and ovarian activity of buffaloes in different months. Indian Veterinary Journal 49 54-60.

Sansone G, Nastri MJE \& Fabbrocini A 2000 Storage of buffalo (Bubalus bubalis) semen. Animal Reproduction Science 62 55-76.

Sarvaiya NP \& Pathak MM 1992 Profiles of progesterone, 17B-oestradiol, triiodothyronine and blood biochemical parameters in Surti buffalo. Buffalo lournal 8 23.30.

Sejrsen K, Oksbjerg N, Vestergaard M \& Sorensen MT 1996 Growth hormone and related peptides as growth promoters. In Proceedings of Scientific Conference on Growth Promotion in Meat Production, pp 87-119, Brussels, Belgium.

Singh J 1990 Prolactin and hypophysial-gonadal functions in buffaloes. PhD thesis. National Dairy Research Institute, Deemed University, Karnal, India.

Singh M \& Madan ML 1985 Plasma lestosterone during oestrous cycle and post partum period among buffaloes. Indian Journal of Animal Reproduction 6 1316.

Singh J \& Madan ML 1993 RIA of prolaclin as related to circadian changes in buffaloes. Buffalo Journal 9159. 164.

Singh C \& Madan ML 1998a Pituitary and gonadal response to GnRH to prepubertal buffaloes (Bubalus bubalis). Asian-Australasian lournal of Animal Science 11 78-83.

Singh C \& Madan ML 1998 b Hypophyseal and gonadal response to $\mathrm{GnRH}$ in buffalo heifers (Bubalus bubalis) Asian-Australasian Journal of Anima/ Science $11416-$ 421.

Singh C \& Madan ML 1999a The ovarian response of prepubertal buffaloes (Bubatus bubalis) to superovulation in equine chorionic gonadotrophin with and without treatment with GnRH. Veterinary lournal 158 155-158.

Singh C \& Madan ML 1999b Ovarian response to equine chorionic gonadotrophin (eCG) and $\mathrm{GnRH}$ in buffalo heifers (Bubalus bubalis). Indian journal of Animal Science $69492-493$.

Singh C \& Madan ML 2000a circulatory level of follicle stimulating hormone $(\mathrm{FSH})$ in Murrah buffalo heifers (Bubalus bubalis). Indian journal of Animal $5 \mathrm{ci}$ ence $70 \quad 403-404$.

Singh C \& Madan ML 2000 b Plasma prolactin concenIration in Murrah buffalo heifers (Bubalus bubalis) with and without $\mathrm{GnRH}$ administration. Indian four- 
nal of Animal Science 70 933-935.

Singh C \& Madan ML 2000c Effect of PGF $2 \alpha$ and $\mathrm{AnRH}$ during different ovarian status at onset of puberty in Murrah buffalo heifers (Bubalus bubalis). AsianAustralasian Journal of Animal Science 131059 1062.

Singh C \& Madan ML 2002a Hypophyseal and gonadal response to PGF $2 \alpha$ and $G n R H$ at onset of puberty in Murrah buffalo heifers. Indian Journal of Animal Science 72 431-533.

Singh C \& Madan ML 2002b Plasma prolactin concentration in non-cycling Murrah buffalo heifers. Indian Journal of Animal Science 72 841-843.

Singh J, Nanda AS \& Adams GP 2000 The reproductive pattern and efficiency of female buffaloes. Animal Reproduction Science 60-61 593-604.
Singla SK, Manik RS \& Madan ML 1996 Embryo biotechnology in buffaloes: A review. Bubalus bubalis 1 . $53-63$.

Singla SK, Manik RS \& Madan ML 1997 Micromanipulation and cloning studies on buffalo oocytes and embryos using nucleus transfer. Indian Journal of Experimental Biology 35 1273-1283.

Thorburn GD, Challis Jr RG \& Currie WB 1977 Control of parturition in domestic animals. Biology of Reproduction 16, 18-29.

Tiwari SR \& Pathak MM 1995 Influence of suckling on postpartum reproduction performance of Surti buffaloes. Buffalo Journal 2 213-217. 